\title{
Compared activity of agonist molecules towards ecdysone receptor in insect cell-based screening system
}

\section{Comparação da atividade de moléculas agonistas em relação ao receptor de ecdisona em um sistema de triagem baseado em linhagens celulares de insetos}

\author{
Ciro Pedro Guidotti Pinto ${ }^{1,2 *}$ (D), Letícia Neutzling Rickes ${ }^{2}$ (D), Moisés João Zotti ${ }^{2}$ (D), \\ Anderson Dionei Grutzmacher ${ }^{2}$ (D)
}

\begin{abstract}
The ecdysone receptor, naturally activated by steroidal hormones, is a key protein for molting and reproduction processes of insects. Artificial activation of such receptor by specific pesticides induces an anomalous process of ecdysis, causing death of insects by desiccation and starvation. In this paper, we established a protocol for screening agonistic molecules towards ecdysone receptor of insect cells line S2 (Diptera) and Sf9 (Lepidoptera), transfected with the reporter plasmid ere.b.act.luc. Therefore, we set dose-response curves with the ecdysteroid 20-hydroxyecdysone, the phytoecdysteroid ponasterone-A, and tebufenozide, a pesticide belonging to the class of diacylhydrazines. In both cell lines, the median effective concentration values on reporter gene induction $\left(\mathrm{EC}_{50}\right)$ of ponasterone-A was the smallest, meaning the most active agonist molecule. In Sf9 cells, tebufenozide had as smaller $\mathrm{EC}_{50}$ than 20-hydroxyecdysone, indicating the high agonistic capability and lepidopteran specificity. The protocol established in this study can be useful for a quick screening and rational research of site-specific pesticides.
\end{abstract}

KEYWORDS: plasmid; tebufenozide; 20-hydroxyecdysone; ponasterone-A.
RESUMO: O receptor de ecdisona, naturalmente ativado por hormônios esteroidais, é uma proteína-chave nos processos de muda e reprodução de insetos. A ativação artificial desse receptor por meio de pesticidas específicos induz um processo de ecdise anômala, levando o inseto à morte por dessecação e inanição. Neste trabalho, foi estabelecido um protocolo para a triagem de moléculas agonistas em relação ao receptor de ecdisona nas linhagens celulares responsivas S2 (Diptera) e Sf9 (Lepidoptera), transfectadas com o plasmídeo repórter ere.b.act.luc. Para tanto, curvas de dose-resposta foram estabelecidas com o ecdisteroide 20-hidroxiecdisona, o fitoecdisteroide ponasterona-A e tebufenozida, um pesticida pertencente à classe das diacilhidrazinas. Em ambas linhagens celulares, os valores médios de concentraçáo efetiva para indução gênica $\left(E_{50}\right)$ ponasterona-A foram menores, significando que este é o agonista mais potente. Em células Sf9, a tebufenozida apresentou $\mathrm{EC}_{50}$ menor que a 20-hidroxiecdisona, indicando uma alta atividade agonista e especificidade deste inseticida a lepidópteros. O protocolo estabelecido neste trabalho pode ser utilizado para uma rápida triagem e busca racional de pesticidas de alvo bioquímico específico.

PALAVRAS-CHAVE: plasmídeo; tebufenozida; 20-hidroxiecdisona; ponasterona-A.

\footnotetext{
'Universidade Estadual Paulista “Júlio de Mesquita Filho" - Jaboticabal (SP), Brazil

"Universidade Federal de Pelotas - Pelotas (RS), Brazil

*Corresponding author: ciro.pedro@ufpel.edu.br

Received on: 04/27/2019. Accepted on: 09/11/2019
} 
The ecdysone receptor is a protein that belongs to the family of Nuclear Receptors that are involved in the processes of insects molting, metamorphosis and reproduction. Knowledge of the function and structure of ecdysteroids and their receptor allowed the development of non-steroidal compounds with agonist activity, mainly represented by the insecticide class of diacylhydrazines (WING et al., 1988). Although these compounds are used as pesticides, especially for controlling harmful lepidopterans and some mites in crops, there are few diacylhydrazines registered for commercial use.

In addition to diacylhydrazines, different chemical groups of non-steroidal compounds, such as oligobestenes (MENG et al., 2001), alkaloids (DINAN et al., 2001), $\alpha$-acylaminoketones (TICE et al., 2003), acylaminoketones, tetrahydroquinolines (SOIN et al., 2010) or unclassified molecules (HARADA et al., 2011; HU, et al., 2018) exhibit agonist or antagonist activity at insect ecdysone receptor. Thus, ecdysone receptor is a poorly explored, but interesting target for continuous search of a broad range of safer and selective molecules.

Cell lines secrete all necessary components for activating and transactivating the ecdysone receptor (ZOTTI et al., 2013). Thus, cell-based bioassays associated with screening of chemical libraries may be used for the prospection of selective insecticides. Therefore, the objective of this study was to propose a rapid and specific protocol for screening molecules based on the activation of ecdysone receptor in cell lines. For this, based on dose response curves, we estimated activity patterns of different agonist molecules towards dipteran (S2) and lepidopteran (Sf9) cell lines.

The Sf9 cell line, derived from embryonic cells of Spodoptera frugiperda (J. E. Smith, 1797) (Lepidoptera: Noctuidae), was maintained at $27^{\circ} \mathrm{C}$ in $\mathrm{SF} 900^{\mathrm{TM}}$ cell culture medium $\left(\mathrm{Gibco}^{\circledR}\right)$. The S2 cell line, derived from embryonic cells of Drosophila melanogaster (Meigen, 1830) (Diptera: Drosophilidae), was maintained at $27^{\circ} \mathrm{C}$ in InsectXpress ${ }^{\mathrm{TM}}\left(\operatorname{Lonza}^{\circledR}\right)$ culture medium.

Cells were transiently transfected with the plasmid ere.b.act. $l u c$. , a reporter constructed specifically for the detection of ecdysone receptor activity. The plasmid was constructed with seven copies of the Drosophila ecdysone response element hsp 27 (ere.), the basal actin promoter (b. act.), the firefly luciferase enzyme as reporter gene ( $l u c$.$) and a termination signal$ (SWEVERS et al., 2004). Thus, molecules were assayed for their ability to promote ecdysone receptor activation, which is measurable according to the light emitted by the luciferase enzyme in transfected cells with the reporter plasmid.

For preparing the transfection medium for $\mathrm{S} 2$ cells, $497 \mu \mathrm{L}$ of culture medium was added to an Eppendorf tube followed by $3 \mu \mathrm{L}$ of transfection reagent Escort IV ${ }^{\mathrm{TM}}$ (Sigma-Aldrich ${ }^{\circledR}$ ) and $100 \mathrm{ng}$ reporter plasmid. The reaction was incubated at room temperature (RT) for 30 minutes. For Sf9 cells, transfection medium was prepared with $496 \mu \mathrm{L}$ culture medium, $4 \mu \mathrm{L}$ of transfection reagent and $300 \mathrm{ng}$ reporter plasmid were mixed into an Eppendorf tube, and also incubated at RT for 30 minutes.

Prior to the transfection itself, the 24-well plates were filled with $5 \times 10^{5}$ and $3 \times 10^{5}$ cells of $S 2$ and $S f 9$, respectively. Cell counting was performed with a Neubauer Chamber and Trypan Blue (Sigma-Aldrich) as a cell viability reagent. A period of 1 hour was expected for cells to adhere to the bottom of the plate. Subsequently, the culture medium was withdrawn and replaced by the transfection medium. Both cell lines were incubated for 5 hours with the transfection medium, previously described. After this time, the transfection medium was withdrawn and replaced with fresh culture medium.

To establish this screening system, in both cell lines we estimated the $\mathrm{EC}_{50}$ of two steroidal agonists, 20-hydroxyecdysone and ponasterone-A (Sigma-Aldrich), and one nonsteroidal compound of the diacylhydrazine group, the tebufenozide (Sigma-Aldrich) (Fig. 1). The carrier solvent used was ethanol, in which serial dilutions of the molecules were performed to obtain a robust dose response curve and as negative control, we used pure ethanol. For each concentration, 1 and $1.5 \mu \mathrm{L}$ of the diluted molecules were added to the $\mathrm{S} 2$ and Sf9 cell plates, respectively.

Luminescence was measured 24 hours after the molecules were added to the cells. Thus, cells were resuspended and $100 \mu \mathrm{L}$ of them were transferred to wells of a white 96-well plate. Thereafter, $100 \mu \mathrm{l}$ of the luciferase substrate (Steady-Glo Luciferase Assay System Kit) was also added to the 96 well plate. The model of the luminometer used was VitorTM X5 and readings started 5 minutes after the addition of luciferase substrate into the 96-well plates. Each treatment was performed in quadruplicate, and the experiments were performed 4 times. $\mathrm{EC}_{50}$ values (mean effective concentration values for induction of Luciferase enzyme) were calculated with $95 \%$ reliability and transformed into $\log X$ using GraphPad Prism v.4 software (GraphPad Software Inc. La Jolla, Ca) and the accuracy of the data evaluated based on $\mathrm{R}^{2}$ values.

The $\mathrm{EC}_{50}(\log \mathrm{X})$ of tebufenozide in $\mathrm{S} 2$ was -3.4 , whereas in Sf9 it was -5.1 , i.e., the activity of this molecule in Lepidoptera cells was almost 100 times higher than in Diptera (Fig. 1 and Table 1). The concentration of tebufenozide required to activate the ecdysone receptor of $\mathrm{S} 2$ to an $80 \%$ equivalent observed in hormones was in the millimolar range, highlighting the low specificity of this molecule for Diptera.

The 20-hydroxyecdysone $\mathrm{EC}_{50}$ was -4.9 and -4.21 , whereas ponasterone-A values were -5.57 and -5.27 for Diptera and Lepidoptera cells, respectively (Table 1), i.e., ponasterone-A was approximately 10 times stronger than 20-hydroxyecdysone in both cell lines. Both steroidal compounds were nonspecific due to similar activity patterns, confirming what was also attested for Hemiptera (TOHIDI-ESFAHANI et al., 2011).

Tebufenozide (diacylhydrazine) bind with higher affinity in lepidopteran ecdysone receptor than in dipteran (Fig.1; Table 1). Even though, studies with larvae of Anopheles gambiae 
Giles, 1926 (Diptera: Culicidae) found that some diacylhydrazines, such as methoxifenozide and KU-106, cause similar symptoms to those seen in lepidopterans, such as earlier ecdysis and malformations (BECKAGE et al., 2004; MOROU et al., 2013). Our results show that tebufenozide can activate ecdysone receptor of S2 cells. It points out that the ecdysone receptor of Diptera presents a flexibility, that allows binding of tebufenozide, which makes the search for novel ecdysone receptor agonist pesticides available.

The 20-hydroxyecdysone is the most representative ecdysteroid of the insects; however, in this study, we show that phytoecdysteroids may have a higher activation power (Fig. 1). Phytoecdysteroids are found in approximately $6 \%$ of the plant species and more than 500 ecdysteroids, including from fungi, have been identified in the nature (ECDYBASE, 2019).

The ability of plants to produce active phytoecdysteroids may be an evolutionary adaptation, and the activity of these compounds may vary among insect orders (DINAN et al.,
2001). In this paper, we show the high activity of Ponasterone-A as an ecdysone receptor agonist (Fig. 1). This phytoecdysteroid can cause similar symptoms to insecticides, such as diacylhydrazines, when absorbed in the insect mesenteric, representing a significant barrier against herbivory (BOWERS, 2012; CHAUBEY, 2018).

Phytoecdysteroids such as castasterone, may have a higher affinity for dipteran rather than the lepidopteran ecdysone receptor, unlike diacylhydrazines (ZOTTI et al., 2013). Furthermore, phytoecdysteroids are also capable of antagonizing the 20-hydroxyecdysone hormone, as already documented in Phormia terranovae Robineau-Desvoidy, 1830 (Diptera: Calliphoridae) and Thrips tabaci Lindeman, 1889 (Thysanoptera: Thripidae) (HETRU et al., 1986; RICHTER; KOOLMAN, 1991; MIYAJI et al., 2014).

In the present study, we established a protocol for the search of ecdysone receptor agonist compounds by verifying different activation patterns of molecules from different origins
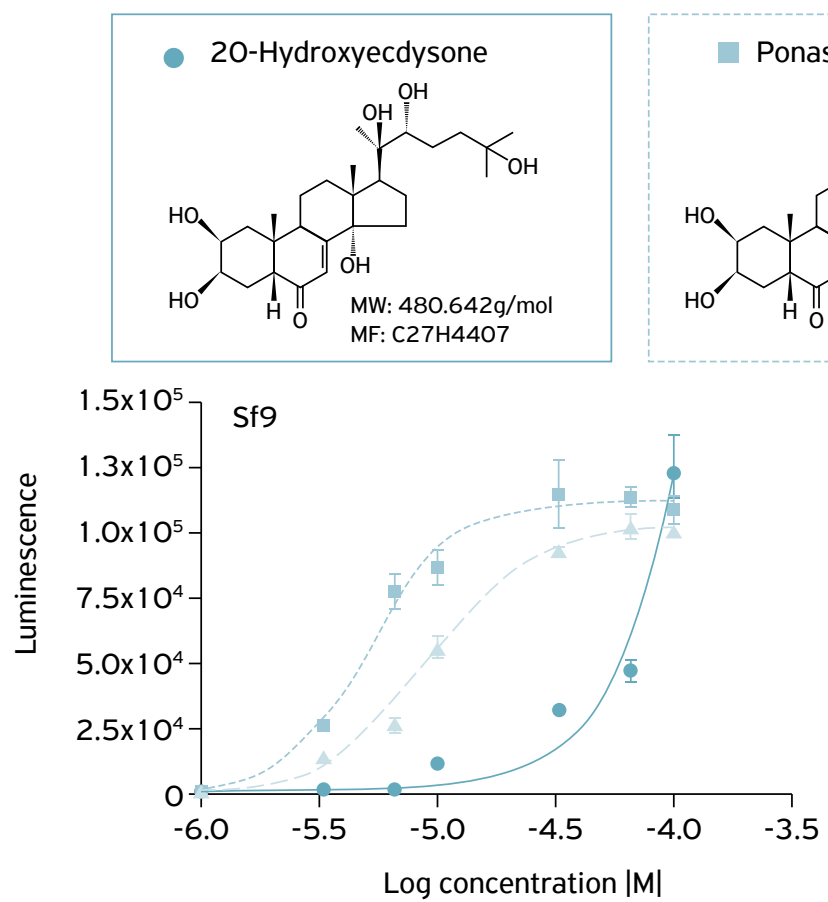

Ponasterone-A<smiles>CC(C)CCC(O)C(C)(O)C1CCC2(C)C1CCC1C3(C)CC(O)C(O)CC3C(=O)C(N)CC12C</smiles>

$\left.1.0 \times 10^{6}\right] \mathrm{S} 2$

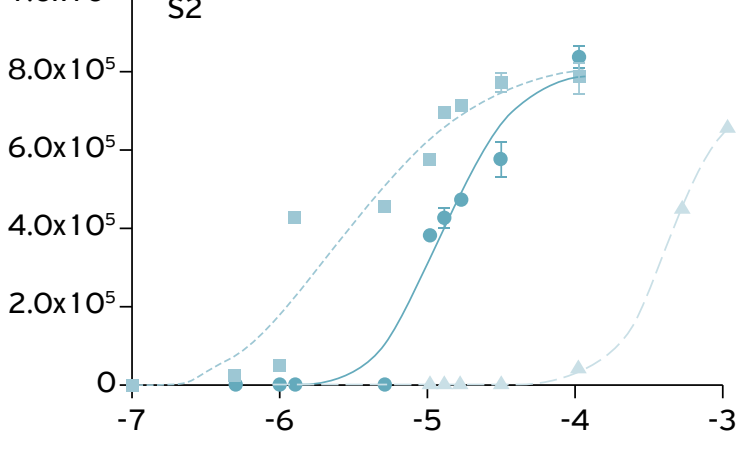

Log concentration |M|

Bars represent means \pm standard errors. MW: molecular weight; MF: molecular formula.

Figure 1. Dose-response sigmoid curves referring to the activity of the ecdysteroid 20-hydroxyecdysone, the phytoecdysteroid ponasterone-A, and the non-steroidal agonist tebufenozide in lepidopteran (Sf9) and dipteran (S2) cells.

Table 1. Agonistic activity of 20-hydroxyecdysone, ponasterone-A and tebufenozide in S2 and Sf9 cell lines.

\begin{tabular}{|c|c|c|c|c|c|c|}
\hline & \multicolumn{3}{|c|}{ S2 } & \multicolumn{3}{|c|}{ Sf9 } \\
\hline & $-\log E C_{50}$ & $95 \%$ IC & $\mathbf{R}^{2}$ & $-\log \mathrm{EC}_{50}$ & $95 \%$ IC & $\mathbf{R}^{2}$ \\
\hline $2 \mathrm{OH}$ & 4.90 & $4.98-4.78$ & 0.964 & 4.21 & $4.28-4.12$ & 0.889 \\
\hline PonA & 5.57 & $5.85-5.30$ & 0.920 & 5.27 & $5.31-5.24$ & 0.984 \\
\hline Tebu & 3.4 & $3.41-3.38$ & 0.999 & 5.01 & $5.03-4.99$ & 0.994 \\
\hline
\end{tabular}

Data are given as median response values together with the $95 \%$ confidence interval (both in - $\log \mathrm{EC}_{50}$ ).

$\mathrm{R}^{2}$ represents the accuracy of data fitting to the sigmoid curve. 
(Fig. 1). Besides that, another possibility is the search for antagonistic compounds to the ecdysone receptor, expanding the possibilities of discovery (HU et al., 2018). For example, compounds derived from Cyperaceae, such as resveratrol, are capable of competing for the active site with ponasterone-A and 20-hydroxyecdysone, generating antagonistic activity in dipteran cells (MENG et al., 2001).

Ecdysone receptor cell-based assays are useful to find the pattern of activation of compounds or to identify new bioactive molecules. Once the workflow is established, this kind of assay allows testing several molecules with a relatively low cost of time, space and financial resources, especially because there is no need for insect rearing. Even though, if research focuses on finding new bioactive molecules, subsequent to cell-based assays, the ideal is testing promising compounds on whole organisms (SWEVERS; SMAGGHE, 2016). Several molecules capable of activating the ecdysone receptor of Sl2 cell line, derived from Spodoptera littoralis (Boisduval, 1833)
(Lepidoptera: Noctuidae), were shown to be ineffective when tested in vivo (SOIN et al., 2010). In addition, virtual substituted diacylhydrazine radicals may vary in toxicity in vivo, unlike predicted by virtual screening (DENG et al., 2016).

The insect cell-based screening system, highly specific for ecdysone receptor, established in this work is an agile, sustainable and relatively inexpensive methodology for testing a wide range of different molecules. The 20-hydroxyecdysone, Ponasterone-A and tebufenozide can be used as a standard and a comparative for other compounds.

\section{ACKNOWLEDGEMENTS}

This study was partly financed by Coordenação de Aperfeiçoamento de Pessoal de Nível Superior (CAPES), Brasil, Finance Code 001.

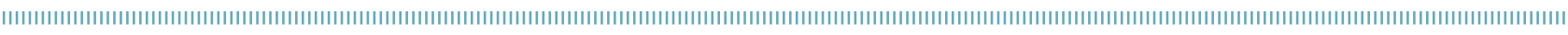
REFERENCES

BECKAGE, N.E.; MARION, K.M.; WALTON, W.E.; WIRTH, M.C.; TAN, F.F. Comparative larvicidal toxicities of three ecdysone agonists on the mosquitoes Aedes aegypti, Culex quinquefasciatus, and Anopheles gambiae. Archives of Insect Biochemistry and Physiology, v.57, n.3, p.111-122, 2004. https://doi.org/10.1002/arch.20021

BOWERS, W.S. Insect hormones and antihormones in plants. In: ROSENTHAL, G.A.; BERENBAUM, M.R. (Eds.). Herbivores: their interactions with secondary plant metabolites. Toronto: Academic Press, 2012. p.431-456.

CHAUBEY, M.K. Role of phytoecdysteroids in insect pest management: a review. Journal of Agronomy, v.17, n.1, p. 1 10, 2018. http://dx.doi.org/10.3923/ja.2018.1.10

DENG, X.L.; XIE, J.; LI, Y.Q.; YUAN, D.K.; HU, X.P.; ZHANG, L.; YANG, $X . L$. Design, synthesis and biological activity of novel substituted pyrazole amide derivatives targeting EcR/USP receptor. Chinese Chemical Letters, v.27, n.4, p.566-570, 2016. http://dx.doi. org/10.1016/j.cclet.2016.02.009

DINAN, L.; BOURNE, P. C.; MENG, Y.; SARKER, S. D.; TOLENTINO, R. B.; WHITING, P. Assessment of natural products in the Drosophila melanogaster Bll cell bioassay for ecdysteroid agonist and antagonist activities. Cellular and Molecular Life Sciences, v.58, n.2, p.321-342, 2001. https://doi.org/10.1007/PL00000859

ECDYBASE. The Ecdysone Handbook. Available from: <http:// ecdybase.org/>. Access on: Apr. 212019.

HARADA, T.; NAKAGAWA, Y.; OGURA, T.; YAMADA, Y.; OHE, T.; MIYAGAWA, $H$. Virtual screening for ligands of the insect molting hormone receptor. Journal of Chemical Information and Modeling, v.51,n.2, p.296-305, 2011 . https://doi.org/10.1021/ci100400k
HETRU, C.; ROUSSEL, J.P.; MORI, K.; NAKATANI, Y. Activité antiecdysteroide de Brassinosteroides. Comptes Rendus de l'Academic des Sciences, v.302, p.417-420, 1986.

HU, X.; YIN, B.; CAPPELLE, K.; SWEVERS, L.; SMAGGHE, G.; YANG, X.; ZHANG, L. Identification of novel agonists and antagonists of the ecdysone receptor by virtual screening. Journal of Molecular Graphics and Modelling, v.81, p.77-85, 2018. https://doi. org/10.1016/j.jmgm.2018.02.016

MENG, Y.; BOURNE, P.C.; WHITING, P.; ŠIK, V.; DINAN, L. Identification and ecdysteroid antagonist activity of three oligostilbenes from the seeds of Carex pendula (Cyperaceae). Phytochemistry, v.57, n.3, p.393-400, 2001 . https://doi.org/10.1016/ s0031-9422(01)00061-9

MIYAJI, T.; YAMAGAMI, A.; KUME, N.; SAKUTA, M.; OSADA, H.; ASAMI, T.; ARIMOTO, Y.; NAKANO, T. Brassinosteroid-related transcription factor BIL1/BZR 1 increases plant resistance to insect feeding. Bioscience, Biotechnology and Biochemistry, v.78, n.6, p.960-968, 2014. https://doi.org/10.1080/09168451 .2014 .910093

MOROU, E.; LIRAKIS, M.; PAVLIDI, N.; ZOTTI, M.; NAKAGAWA, Y.; SMAGGHE, G.; VONTAS, J.; SWEVERS, L. A new dibenzoylhydrazine with insecticidal activity against Anopheles mosquito larvae. Pest Management Science, v.69, n.7, p.827-833, 2013. https://doi. org/10.1002/ps.3441

RICHTER, K; KOOLMAN, J. Antiecdysteroid effects of brassinosteroids in insects. In: Cutler, H. G.; YOKOTA T.; ADAM, G. (Eds.). Brassinosteroids: Chemistry, Bioactivity, and Applications. Acs Symposium Series, 1991, p.265-278. https://doi.org/10.1021/ bk-1991-0474.ch023 
SOIN, T.; DE GEYTER, E.; MOSALLANEJAD, H.; IGA, M.; MARTÍN, D.; OZAKI, S.; KITSUDA, S.; HARADA, T.; MIYAGAWA, H.; STEFANOU, D.; KOTZIA, G.; EFROSE, R.; LABROPOULOU, V.; GEELEN, D.; IATROU, K.; NAKAGAWA, Y.; JANSSEN, C.R.; SMAGGHE, G.; SWEVERS L. Assessment of species specificity of moulting accelerating compounds in Lepidoptera: comparison of activity between Bombyx mori and Spodoptera littoralis by in vitro reporter and in vivo toxicity assays. Pesticide Science, v.66, n.5, p.526-535, 2010. https://doi.org/10.1002/ps.1903

SWEVERS, L.; KRAVARITI, L.; CIOLFI, S.; XENOU-KOKOLETSI, M.; RAGOUSSIS, N.; SMAGGHE, G.; NAKAGAWA, Y.; MAZOMENOS, B.; IATROU K. A cell-based high-throughput screening system for detecting ecdysteroid agonists and antagonists in plant extracts and libraries of synthetic compounds. The FASEB Journal, v. 18, n. 1, p.134-136, 2004.

SWEVERS, L.; SMAGGHE, G. Cell-based screening systems for developing novel insecticides: insights from the ecr-reporter paradigm. In: HOROWITZ, A.R.; ISHAAYA, I. (Eds.). Advances in insect control and resistance management. Springer International Publishing, 2016. p.191-204. https://doi. org/10.1007/978-3-319-31800-4_10
TICE, C.M.; HORMANN R.E.; THOMPSON, C.S.; FRIZ, J.L.; CAVANAUGH, C.K.; MICHELOTTI, E.L. Synthesis and SAR of alpha-acylaminoketone ligands for control of gene expression. Bioorganic \& Medicinal Chemistry Letters, v. 13, n.3, p.475-478, 2003. https://doi.org/10.1016/S0960-894X(02)00980-0

TOHIDI-ESFAHANI, D.; GRAHAM, L.D.; HANNAN, G.N.; SIMPSON, A.M.; HILL, R.J. An ecdysone receptor from the pentatomomorphan, Nezara viridula, shows similar affinities for moulting hormones makisterone $A$ and 20-hydroxyecdysone. Insect Biochemistry and MolecularBiology, v.41, n.2, p.77-89, 201 1. https://doi.org/10.1016/j.ibmb.2010.10.002

WING, K.D.; SLAWECKI, R.A.; CARLSON, G.R. RH 5849, a nonsteroidal ecdysone agonist: effects on larval Lepidoptera. Science, v.241, n.4864, p.470-472, 1988. https://doi.org/10.1126/science.241.4864.470

ZOTTI, M.J.; GEYTER, E;; SWEVERS, L; BRAZ, A.S.; SCOTT, LP.B.; ROUGÉ, P.; COLL, J.; GRUTZMACHER, A.D.; LENARDÃO, E.J.; SMAGGHE, G. A cell-based reporter assay for screening for EcR agonist/antagonist activity of natural ecdysteroids in Lepidoptera (Bm5) and Diptera (S2) cell cultures, followed by modeling of ecdysteroid-EcR interactions and normal mode analysis. Pesticide Biochemistry and Physiology, v.107, n.3, p.309-320, 2013.https://doi.org/10.1016/j.pestbp.2013.09.003 